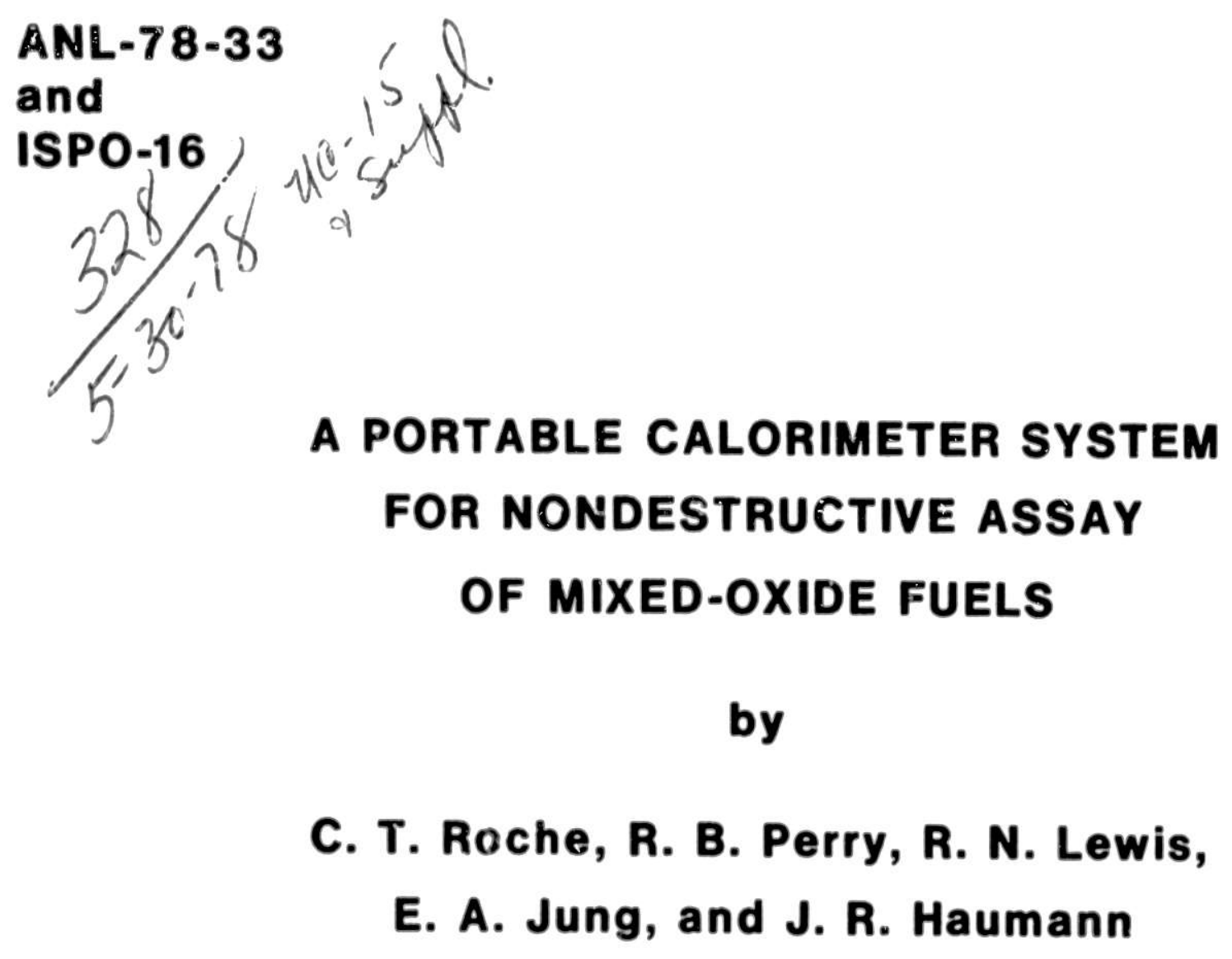

$2-112$

ANL-78-33

and

ISPO-16

\title{
A PORTABLE CALORIMETER SYSTEM FOR NONDESTRUCTIVE ASSAY OF MIXED-OXIDE FUELS
}

by

C. T. Roche, R. B. Perry, R. N. Lewis, E. A. Jung, and J. R. Haumann
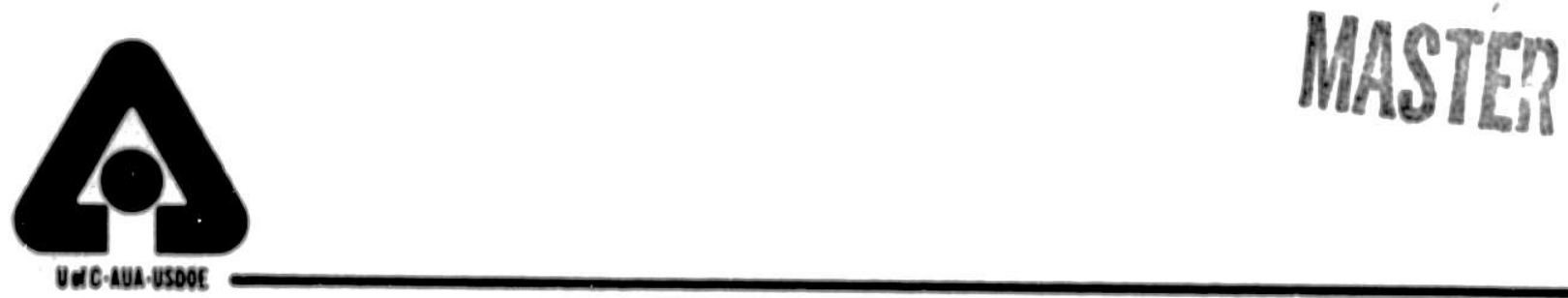

ARGONNE NATIONAL LABORATORY, ARGONNE, ILLINOIS

Prepared for the U. S. DEPARTMENT OF ENERGY

under Contract W-31-109-Eng-38 DSTREUTION OF THLS DUCUMENT LS UNLIMUTED 



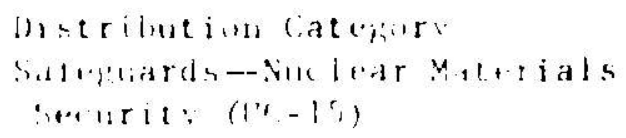



TABLE OF CONTPNTS

Page

ABSTRACT . . . . . . . . . . . . . . . . . . 1

A. INTRODUCTION . . . . . . . . . . . . . . . . 2

B. RADIOACTIVE DECAY AND SAMPLE SPECIFIC POWER . . . . . . . 2

C. AIR-CHAMBER CALORIMETERS ................ 9

D. SMALL-SAMPLE CALORLMETERS ................. 11

E. DATA ANALYSIS . . . . . . . . . . . . . . . 16

F. RESUTS . . . . . . . . . . . . . . . . 20

REFERENCES ........................... 23 


\section{LIST OF ILLUSTRATIONS}

F1gure

Page

1. The isotopic abundances of a mixej-oxide

11 ht-water reactor (MOX-LWR) fuel as a

function of Irradiation hlatory ........... 7

2. The heat contribution of the lsotopes in MOX-LWR

fuel as a function of 1rradiation history ........ 8

3. The measurement-chamber temperature and power

relations in ANL alr-chamber calorimeters . . . . . 10

4. The ANL small-sample calorimetric system ........ 13

5. A block dlagram of the small-sample calorimeter

with 1 ts measurement and control components .......15

6. Resistance thermometry and feedback control

circuitry in ANL alr-chamber calorimeters . . . . . 17

7. Data analysis flowchart for the

small-sample calorimeter ............. 18

8. Data sheet for the ANL small-sample

calorimeter . . . . . . . . . . . . . 22 


\section{LIST OF TABLES}

Page

I. Nuclear constants for the important heat-producing nuclides in plutonium-bearing meterials . . . . . . 3

II. The 1sotopic abundances of the heat-producing nuclides in typical nuclear fuels . . . . . . . . 6

III. A comparison of an ANL alr-chamber 1sothermal calorimeter with other analytical techniques . . . . 12

IV. An analysis of ZPR-3 plutonium samples with the ANL small-sample calorimeter . . . . . . . . . 21 

A PORTABLE CALOR DMETER SYSTEI FOR NONDESTRUCTIVE ASSAY

OF MIXED-OXIDE FUELS

by

C. T. Roche, R. B. Perry, R. N. Lew1s, E. A. Jung, and J. R. Haumann

\section{ABSTRACT}

Calorimetric assay provides a precise, nondestructive method to determine sample Pu content based on the heat emitted by decaying radionuclides. Th1s measurement, In combination with a gamma-spectrometer analysis of sample Isotopic content, ylelds the total sample Pu mass. The technique is applicable to sealed contalners and 18 essentially independent of sample matrix configuration and elemental composition. Conventional calorimeter designs employ large water-bath heat sinks and lack the portability needed by Inspection personnel. The ANL air-chamber lsothermal calorimeters are lowthermal-capacitance devices which eliminate the need for large constanttemperature heat sinks. These instruments are designed to use a feedback system that applies power to maintain the sample chamber at a constant electrical reslatance and, therefore, at a constant temperature. The applledpower difference between a Pu-contalning sample and a blank determines the radioactive-decay power. Il e operating characterlst1cs of a calorimeter designed for assaying mixed-oxide powders, fuel pellets, and Pu-containing solutions are discussed. Th1s device consists of the calorimeter, sample preheater, and a microprocessor-controlled data-acquisition aystem. The omall-sample device welghs $18 \mathrm{~kg}$ and has a measurement cycle of $20 \mathrm{~min}$, with a precision of 0.17 at $10 \mathrm{~mW}$. A 100 -min gamma-ray measurement gives the opecific power with a precioion of better than 17 for eamples containing 1-2 8 of plutonium. 
A. Introduction

The use of calorimeters to perform a nondestructive determination of the plutonium content of nuclear materials has been well documented.1,2,3 The technique 18 both highly sensitive and precise. Calorfmeters are capable of detecting plutonium concentrations in the 20-ppm range. This corresponds to $0.1 \mu \mathrm{W} / \mathrm{cm}^{2}$, or approximately $0.1 \mathrm{~g}^{239} \mathrm{Pu} / 11$ ter. Precision better than $0.1 \%$ is obtainable on the measurement of plutonium-produced power. ${ }^{4}$ Among the advantages of calorimetry, when compared with other nondestructiveanalysis techniques, are Its Insensitivity to the chemical form of the plutonium and its independence of measurement-bias problems due to sample geometric configuration and sample matrix composition. However, the lack of portability of the instrumentation and the relatively long sample assay time, when compared to neutron and gamma-ray assay procedures, have prevented calorimetry from beisg used as an in-field analytic technique. In designing ANL a1r-chamber 1tothermal calorimeters, we have constructed low-thermal capacitance devices which eliminate the necessity for the large water-bath heat sinks used by classical heat-flow calorimeters. The first of a set of instruments designed to assay the types of plutonium-containing materials encountered by International Atomic Energy Agency (IAEA) inspection personnel has been completed and tested. This device, the "Small-Sample Calorimeter," has been designed to measure the plutonium content of fuel pellets, powders, and solutions. The reduction in instrument size and mass, coupled with the improvement in measurement time should enable inspectors to employ this technique for in-field verification of nuclear safeguards aystems.

\section{B. Radloactive Decay and Sample Specific Power}

Calorimetry 18 a technique which can be used to measure the thermal power produced by decaying radinnuclides. Th1s power 18 related to the nuclide mass through the total decay energy and the specific activity of the disintegration. The nuclear constante for the 1sotopes present in mixedoxide fuel which are of Importance to calorimetric assay are Ilsted in Table I. 4 These Include the plutonium 180topes $(A-238-242)$ and $241_{A m}$. The uranIum 180topes present in MOX fuel are not Included ance the power produced by these nuclides to insignificant when compared to plutonium. 
Table I. Nuclear constants for the fmportant

heat-producing nuclides in plutontumbearing materials.

\begin{tabular}{|c|c|c|c|c|c|c|c|c|c|}
\hline \multirow{2}{*}{$\frac{\text { Muclide }}{241 / n}$} & \multicolumn{2}{|c|}{$\begin{array}{l}Q \\
\text { Total Disintegration } \\
\text { Energy (MeV) }\end{array}$} & \multirow{2}{*}{$\frac{\begin{array}{c}\text { Principle } \\
\text { Decay } \\
\text { Mode }\end{array}}{a}$} & \multirow{2}{*}{$\begin{array}{c}\begin{array}{c}20 \\
\text { Enitted } \\
\text { as } r\end{array} \\
0.38\end{array}$} & \multicolumn{2}{|c|}{$\begin{array}{l}T_{1 / 2} \\
(r)\end{array}$} & \multirow{2}{*}{$\frac{\begin{array}{c}\lambda \\
\left(\text { days }^{-1}\right)\end{array}}{4.372 \times 10^{-6}}$} & \multicolumn{2}{|c|}{$\begin{array}{c}\text { Specific Power } \\
\mathrm{mW} / \mathrm{g}\end{array}$} \\
\hline & 5.6402 & \pm 0.00016 & & & 434.1 & \pm 0.06 & & 114.23 & \pm 0.16 \\
\hline${ }^{230} \mathrm{Pu}$ & 5.5921 & \pm 0.0016 & $a$ & 0.0005 & 87.79 & \pm 0.08 & $2.1617 \times 10^{-5}$ & 567.16 & \pm 0.57 \\
\hline 239pu & 5.2428 & \pm 0.0016 & $a$ & 0.0003 & 24082 . & \pm 46 & $7.880 \times 10^{-8}$ & 1.9293 & \pm 0.0053 \\
\hline $240 P u$ & 5.2551 & \pm 0.0016 & $a$ & 0.0005 & 6537. & \pm 10 & $2.903 \times 10^{-7}$ & 7.098 & \pm 0.015 \\
\hline $241 \mathrm{Pu}$ & 0.00553 & \pm 0.00001 & B & 0.0045 & 14.35 & \pm 0.02 & $7.322 \times 10^{-4}$ & 3.39 & \pm 0.002 \\
\hline $242 p u$ & 4.985 & \pm 0.01 & $a$ & 0.0 & 370399. & \pm 2900 & $5.01 \times 10^{-9}$ & 1.18 & \pm 0.01 \\
\hline
\end{tabular}

1 AMSI n15-22-1975

2 J. M. Meadours, AML/MOH-38 
With the exception of ${ }^{24} \mathrm{Pu}$, the princlpal decay mode of the 1sotopes in Table I is alpha-decay, with a total disintegration energy between 5- 6 MeV. Alpha particles in this energy interval are very short-ranged (< 50 $\mathrm{mg} / \mathrm{cm}^{2}$ of $\left.\mathrm{Al}\right)$. The other major radiations produced by these isotopes, a 5.5 keV beta from ${ }^{24} \mathrm{Pu}$ and a $59.5 \mathrm{keV}$ ganma from ${ }^{241} \mathrm{Am}$, are also short-ranged and, like the alpha's, will deposit their energy within the sample or the measurement-chamber walls. Sources of energy which will not be measured by the calorimeter include high energy gamma-rays, $\bar{v}$, and neutrons; however, these account for 1 ess than $0.01 \%$ of the total-mananargy. Consequently, calorimetry is a technique for which the theoretical detection efficiency approaches $100 \%$.

In order to convert the calorimetrically measured wattage into plutonium content, it is necessary to determine independently the power emitted per gram of sample within a particular isotopic composition. The power emitted by a sample composed of a single 1sotope 1s:

$$
P_{1}=1.1167 \times 10^{3} \times Q \times \lambda \times M_{1} / A
$$

where

$$
\begin{aligned}
& P_{1}-\text { specific power of the 1sotopic } 1(\mathrm{~mW} / \mathrm{g}) \\
& Q_{-}-\text {total disintegration energy (MeV) } \\
& \lambda-\text { decay constant }\left(\text { day }^{-1}\right) \\
& \text { A }- \text { gram atomic weight of 1sotope } 1(\mathrm{~g}) \\
& M_{1}-\text { mass of 1sotope } 1(\mathrm{~g})
\end{aligned}
$$

Most material encountered by IAEA Inspection personnel during an assay contains a mixture of the 1sotopes in Table $I$. Thus, the sample power would be:

$$
P_{S}=\sum M_{1} P_{1}=M_{T} \sum^{n} R_{1} P_{1}=M_{T} P_{\text {eff }}
$$




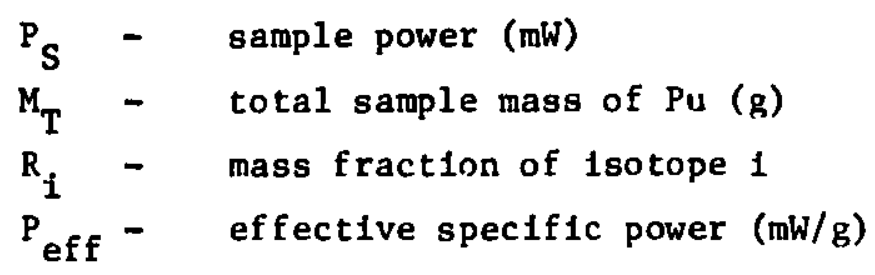

Typical isotopic composition of nuclear fuels which isy he eicountered are given in Table II.5,6 The principal constituent is 2 is $4{ }^{i} \mathrm{ch}$ varies approximately $30 \%$ over the fuels 11sted. The varlation in th. .ilirr principal heat-producing nuclides is 1arger. Plutonfum-240 ranges over a factor of 4, and ${ }^{238} \mathrm{Pu}$ a factor of 10. Americium-241 is the decay product of ${ }^{241} \mathrm{Pu}$, and, consequently, the americtum content of the sample is dependent upon the length of time since the fuel was reprocessed. As a result of the Ingrowth of ${ }^{241} \mathrm{Am}$, the effective specific power of a fuel samplowill increa:e with time. The effective specific power in $\mathrm{mW} / \mathrm{g}$ of $\mathrm{Pu}$ is also given in Tahle II.

The effect of changing isotodic composition on the relative heat concribution of the Isotodes in MOX-LWR (11ght water reactor) fuel is shown in Fip. 1. 2.7 As fuel burn-up proceeds. the relative amounts of the nuclides with large specific Dowers increase. Consequentlv. the $P$ eff for a particular fuel mav varv sienificantlv depending unon its residence time in the reactor.

The effective specific nower mav be determined in two wavs. The first method. referred to as the empirical techniaue, requires that a set of representative samples be collected. These samples are measured calorimetricallv. and a subsequent chemical assav 18 performed to determine their clutonium content. A time spread in the analysis of the sample is necessary to determine the change In specific power due to the ingrowth of ${ }^{241} \mathrm{Am}$. In general. this technique 18 not sultable for inspection personnel because of the time delay required to account for the americtum. The second method, referred to as the computational technique, requires that an 1sotopic analysis be performad and that the mass ratios be used to calculate a welghted-average opecific powar. The 1sotoplc analysis may be performed either by maseopectronotric or NDA techningues. The total assay may be performed nondes- 
Tabje II. The 1sotopic abundances of the heatproducing nuclides in typical nuclear fuels. (The mass ratios are relative to plutonium.)

wt \%

Fuel Type

\begin{tabular}{|c|c|c|c|c|c|c|}
\hline \multirow{2}{*}{ Nucl ide } & \multirow[t]{2}{*}{ LWR } & \multicolumn{2}{|c|}{ FBR (ZPPR) } & \multirow[t]{2}{*}{ British } & \multirow[t]{2}{*}{ Recycle. } & \multirow[t]{2}{*}{ WR } \\
\hline & & $F \& G$ & H & & & \\
\hline $241 \mathrm{Am}$ & 0.7 & 0.15 & $=-$ & 0.1 & 1.5 & 0.05 \\
\hline${ }^{238} \mathrm{Pu}$ & 0.2 & 0.05 & 0.09 & 0.1 & 0.5 & 0.01 \\
\hline${ }^{239} \mathrm{Pu}$ & 75.7 & 86.6 & 68.5 & 90.2 & 65.0 & 93.5 \\
\hline${ }^{240} \mathrm{P}$ & 18.4 & 11.5 & 25.6 & 8.5 & 24.0 & 6.0 \\
\hline${ }^{241} \mathrm{Pu}$ & 4.6 & 1.7 & 4.53 & 1.0 & 8.0 & 0.5 \\
\hline${ }^{242} \mathrm{Pu}$ & 1.1 & 0.2 & 1.4 & 0.2 & 2.5 & 0.05 \\
\hline$P_{\text {eff }}(m W / g)$ & 5.19 & 2.92 & 3.80 & 3.05 & 7.85 & 2.35 \\
\hline
\end{tabular}




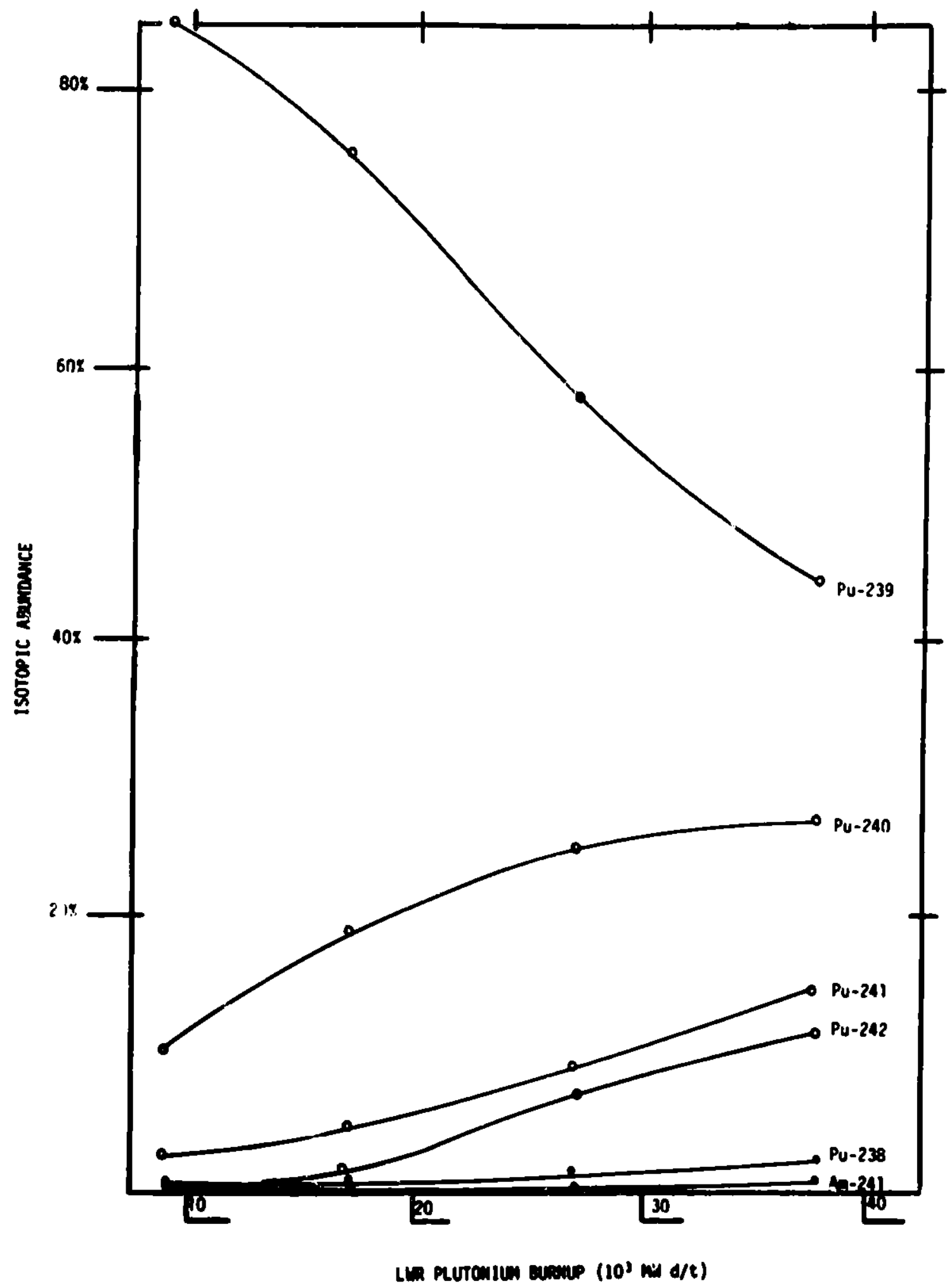

P18. 1. The 1cotopic abundances of a mixed-oxide light-water ractor (MOX-LWR) fuel as a function of irradiation hietory. 


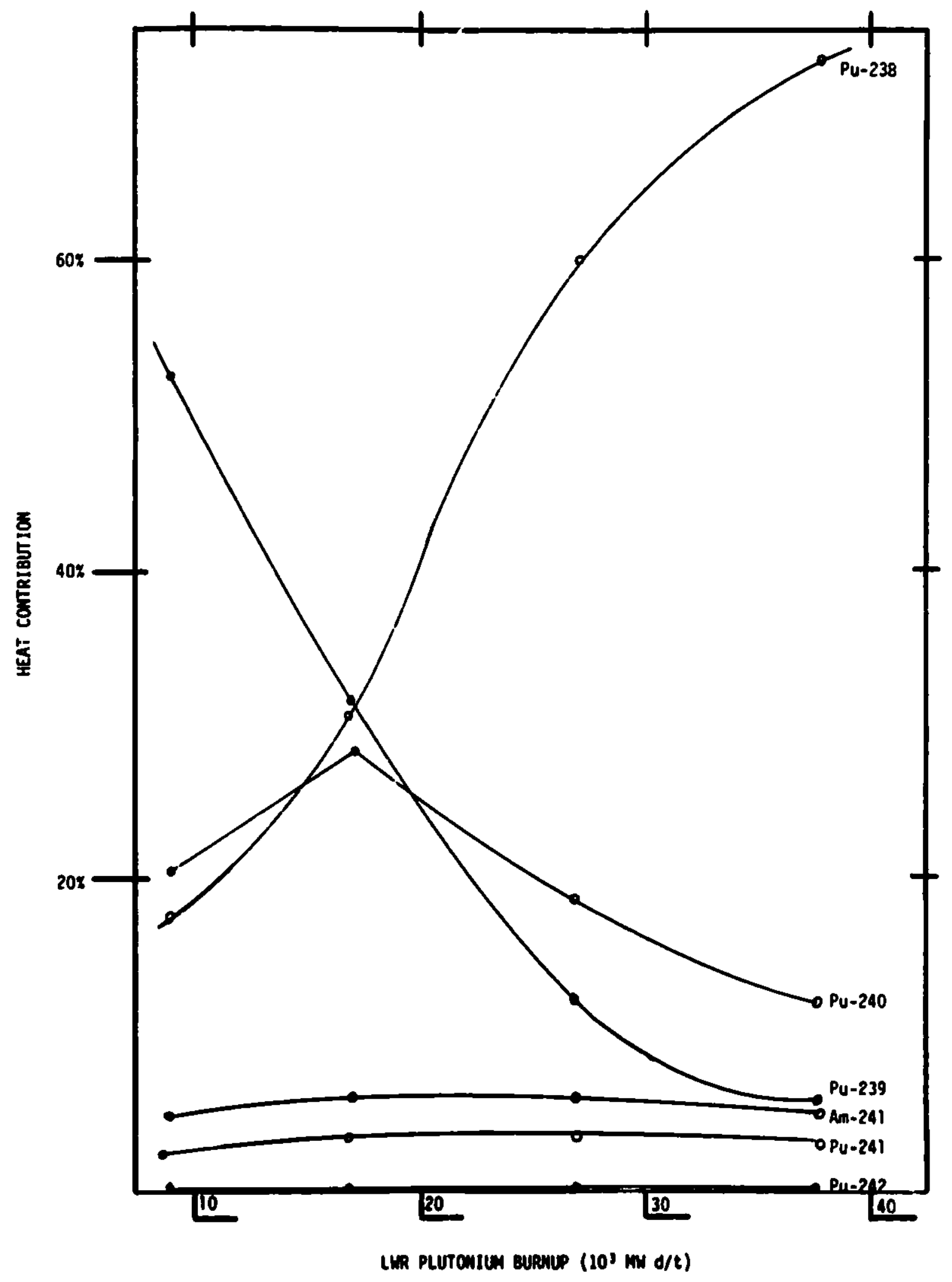

818. 2. The heat contribution of the 1sotopes in MOX-LWR fuel as a

function of 1rradiation history. 
tructively by combining a gamma-spectrometric analysis of the sample 1sotopic with a calorimetric measurement. A 100-min ganma analysis which uses a version of GAMANL, a gammatripping program designed for analysis of plutonium, 8 gives the specific power with a prectsion of better than $1 \%$ for a sample containing 1-2 g of plutonium.

After determining the $P_{\text {eff }}$ for the representative material, the mass of other samples may be determined f rom the relation

$$
\overline{\mathrm{M}}_{\mathrm{S}}=\overline{\mathrm{P}}_{\mathrm{S}} / \mathrm{P}_{\text {eff }}
$$

The uncertainty in the sample mass is given by

$$
\left(s\left(\bar{M}_{S}\right) / \bar{M}\right)^{2}=\left(s\left(\bar{P}_{S}\right) / \bar{P}_{S}\right)^{2}+\left(s\left(P_{\text {eff }}\right) / P_{\text {eff }}\right)^{2}
$$

\section{A1r-Chamber Calor Imeters}

The classical heat-flow calorimeter measures the temperature across a thermal resistance for a plutonfum-containing chamber in contact with a large 1sothermal heat elnk. The entire system is allowed to reach a steadystate condition in which the heat absorbed by the water-bath heat sink is equal to the heat produced by the decaylng radionuclides. The plutoniumproduced power is then proportional to the difference between the sample chamber temperature and the heat-sink temperature. The ANL alr-chamber calor imeters are constructed from a serles of concentric cylinders which act 88 a constant-temperature oven. The servo circults measure the electrical power necessary to maintain this constant temperature. This design eliminates the necessity for a large 1sothermal heat alnk. The temperature-power relatlong in the alr-chamber calorimeter are ahown in P18. 3. At equilibrium an asount of calorimeter-supplied electrical power, $P_{0}$, is necessary to maintain the measurement chaber at some constant tewperature, $T_{3}$. If a fuel sample at some temperature less than $T_{3}$ 1s Inserted Into the measurement chniber, the heaters will apply power to raloe the conbinid sample-sample chabber aystem to $T_{3}$. The total power necessary to restablish $T_{3}$ is $P_{0}$; however, the amount of porrer eupplied by the control clrcults, $P_{C}$ depende 


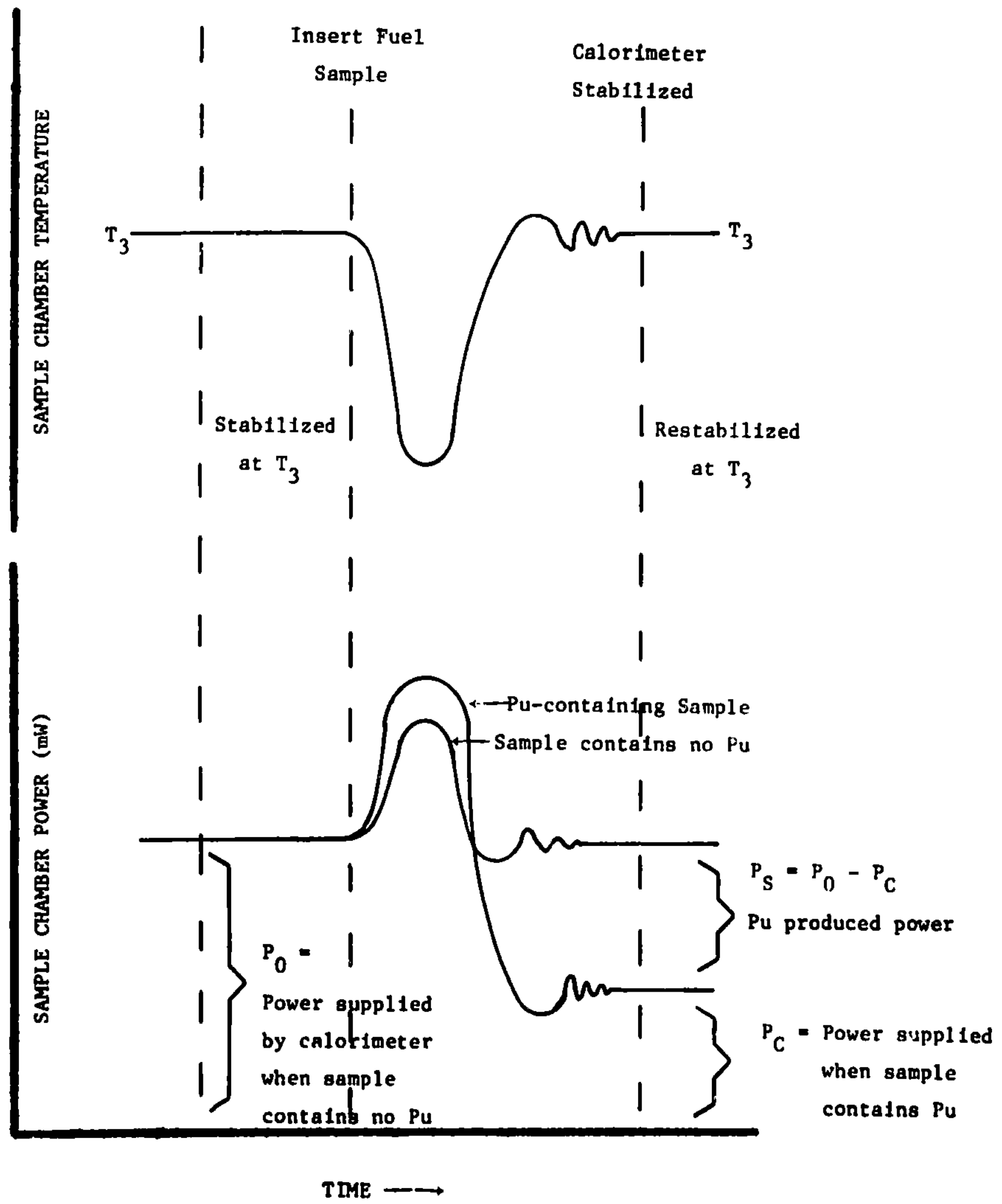

F1g. 3. The measurement-chamber temperature and power relations in ANL air-chamber calorimeters. 
upon the sample composition. If the sample is producing heat due to radioactive decay, then $P_{C}$ w1ll be less than $P_{O}$, and the sample power may be determined by the relation

$$
P_{S}=P_{0}-P_{C}
$$

Table III shows the accuracy attainable with this techntque. In these experiments, ZPPR fuel rods were assayed by neutron-colncidence, gamma-assay, and calorimetric techniques. ${ }^{9}, 10$ The results were compared with a chemical analysis of representative fuel rods. The calorimeter used in these experiments was the ANL Model II, which had an assay time of 20 minutes. The calorimetric results agree with the chemical analysis within experimental uncertainty, while the neutron and gamma assays seem to display a measurement bias. This is a situation where the accuracy of the more rapid assay techniques can be improved by a concurrent calorimetric assay.

\section{Sma11-Sample Calorimeter}

The small-aample calorimeter is shown in Fig. 4. The system consists of two instrument packages: a measurement module and a data-acquisition module. The comblned weight of both packages $1819 \mathrm{~kg}$. The sinall-sample calorimeter is capable of measuring samples producing thermal power up to $32 \mathrm{~mW}$. This $1 \mathrm{~s}$ equivalent to approximately $10 \mathrm{~g}(6 \mathrm{cc})$ of plutonim oxide. This device has a measurement cycle of 20 min with a precision of $0.1 \%$.

The data-acquisition system (DAS) 18 housed in a $47 \mathrm{~cm} \times 35 \mathrm{~cm} \times 16 \mathrm{~cm}$ at tache case and has a welght of $5 \mathrm{~kg}$. It 18 a totally dedicated microprocessor-controlled device designed around the Intel 8085. The DAS obtains calorimetric power data through a 13-bit ADC. The gystem memory consists of 8-K bytes of erasale programable read-only memory (EPRON) and 1-K bytes of random-access memory (RAM). The system program resides in the permanent memory (BPROM) and does not need to be reentered after the device to powered down. The upper 2-K bytes of th1s nonvolat1le merory are located on an EPROA chip residing in the zero-force insertion socket on the face of the unit. The BPROM ch1p rosiding in this socket may be exclivenged for other chipe contalning different programe. This permite the user to develop deta-handing 
Table III. A comparison of an ANL air-chamber Isothermal calorimeter with other analytical techniques.

Physical composition:

$0.95 \mathrm{~cm} \times 15.25 \mathrm{~cm}$ stainless steel clad fuel rods

Chemical composition:

$$
\mathrm{PuO}_{2}, \mathrm{UO}_{2}
$$

Nowinal isotopic composition:

\begin{tabular}{|c|c|c|c|c|c|c|}
\hline & & $238 \mathrm{Pu}$ & $239 \mathrm{Pu}$ & $240 \mathrm{Pu}$ & $241 \mathrm{Pu}$ & $242 p u$ \\
\hline \multirow{2}{*}{ Rod type } & $F, G$ & 0.05 & 86.55 & 11.5 & 1.7 & 0.2 \\
\hline & H & 0.09 & 68.45 & 25.56 & 4.53 & 1.38 \\
\hline
\end{tabular}

Technique

Heutron coincidence

Gama-ray assay

rodel II Calorimeter

Chenistey

\section{Plutonium wt \%}

$\begin{array}{ccc}\frac{F}{G} & \frac{G}{H} \\ 13.35 \pm 0.06 & 26.26 \pm 0.07 & \frac{H}{N A} \\ 13.28 \pm 0.03 & 26.42 \pm 0.04 & N A \\ 13.20 \pm 0.03 & 26.51 \pm 0.03 & 15.73 \pm 0.01 \\ 13.19 \pm 0.02 & 26.48 \pm 0.04 & 15.76 \pm 0.06\end{array}$

*N. S. Beyer, ANL-7906 


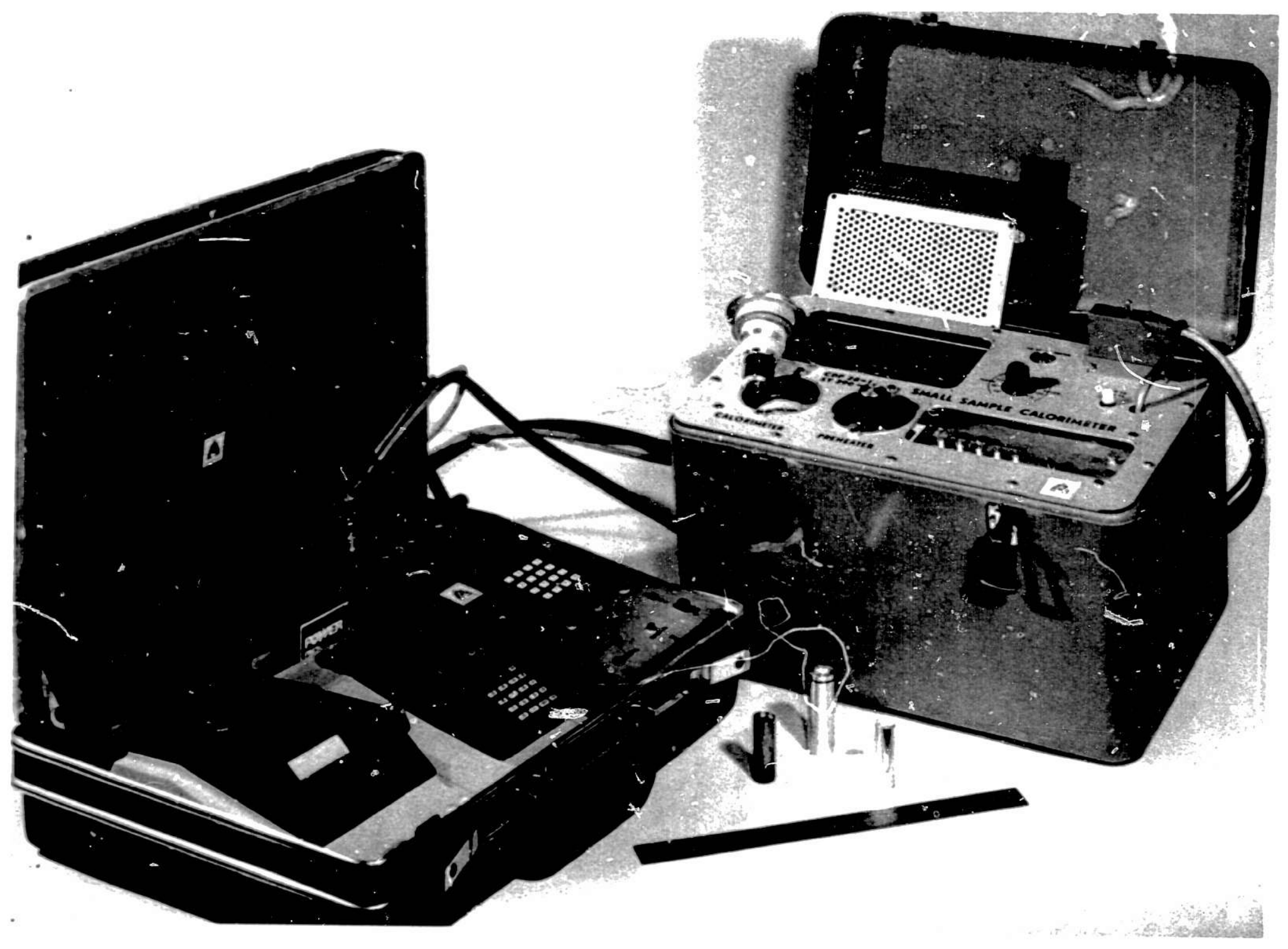

Fig. 4. The ANL small-sample calorimetric system. 
and statistical programs tallored to his speciflc needs.

The software provided with the unit includes a number of data-acquisition and -handling routines. These include codes which calculate the average measurement-chamber electrical power $(\bar{P})$ and 1 ts standard deviation. The DAS will store tire empty uhamber baseline power for comparison with results obtained during a sample assay. Analysis programs are also included to obtain the sample mass and 1 ts uncertainty from the power measurement and the effect.1ve speciflc power. There is also a routine to calculate the $P$ eff from the sample 1sotopic data, as well as a routine to correct mass-fraction data for changes due co radioactive decay.

A double-encapsulation technique using metal sample contalners was chosen to maximize the rate of heat transfer (see F1g. 4). The inner capsule Is an Inexpensive, commerclally avallable drawn-aluminum cylinder with a diameter of $1.6 \mathrm{~cm}$ and a length of $5 \mathrm{~cm}$. It would be sealed Inside a glove box af ter the MOX powder or pellets were linserted and could be disposed of after the assay. The outer sample holder has been machined to minimize the air gap between the Inner capsule and the sample-chamber walls. Ihis cylinder has outer dimensions of $2 \mathrm{~cm}$ in dlameter and $7 \mathrm{~cm}$ in length. It $1 \mathrm{~s}$ f1lled with an " 0 " ring seal to minimize the chance of radiation contamination. By the use of this encapsulation technique, a measurement prectsion of $0.1 \%$ can be obtalned in an equilibration time of $15 \mathrm{~min}$. Equilibration tests were also conducted on sources double-bagged in polyethylene. The poor heatconducting properties of the plastic slowed the equilibration time to about $30 \mathrm{~min}$.

The measurement module contains the calorimeter chamber, the sample preheater, and the control circults. Figure 5 shows the relation between the cylinders comprising the calorimetric unit and the weasurement and control c1rcultry. The small-sample calorimeter 18 constructed of four concentric shells which are maintained at progressively higher temperatures approaching the center of the undt $\left(T_{R O O M}<T_{0}<T_{1}<T_{2}<T_{3}\right)$. Th1s ensures that heat flow will remain constant in the outward direction across the temperature sensing colls. The outer ahelis, $T_{0}$ and $T_{1}$, act as protective buffers for the Inner measurement cylinders. They are controlled by a servo circult which 


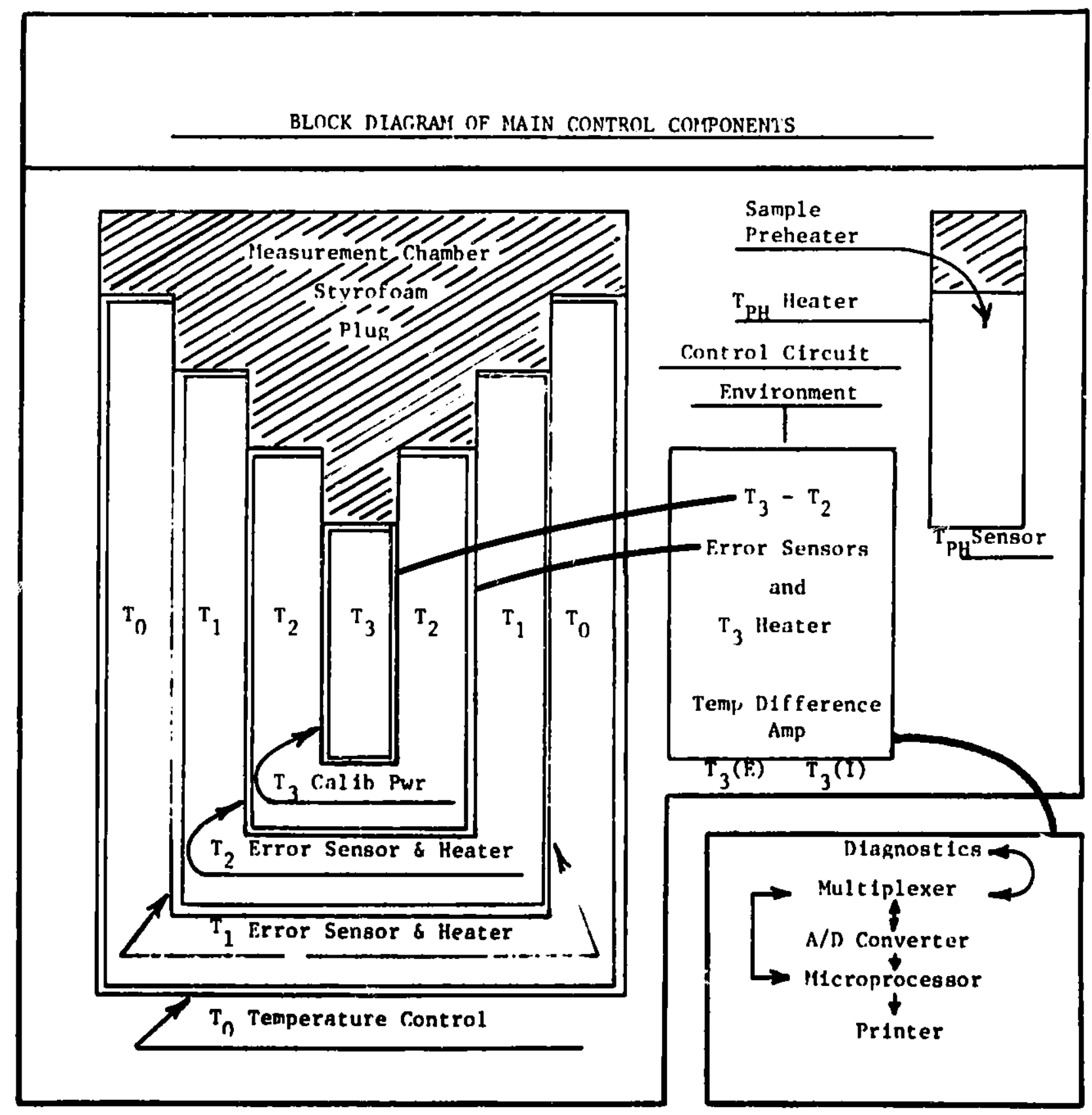

F18. 5. A block diagram of the small-sample calorimeter with 1 ts meseurement and control components. 
has YSI thermistors as sensors and copper colls wound around the aluminum cylinders as heaters. The temperature difference beiween the inner measurement cylinders, $T_{2}$ and $T_{3}$, must be controlled to the microdegree range. The $\mathrm{N}_{1}$ colls on these cylinders act as both temperature sensors and heaters by using the principles of resistance thermometry.

A simplified diagram presenting the control principles used in these clrcults is shown in Fig. 6. The control circults consist of two operationalamplifier (OP-AMP) networks. AMP-A senses the resistance imbalance between a preciston resistor $\left(1 \mathrm{ppm} /{ }^{\circ} \mathrm{C}\right) \mathrm{R}_{\mathrm{A}}$ and the $\mathrm{N}_{1} \operatorname{col} 1, \mathrm{R}_{3}$, wound around the measurement chamber. The resistance of $R_{3}$ is dependent upon the temperature

$$
R_{3}=R_{0}[1+\alpha T]
$$

where

$$
\begin{aligned}
& R_{0} \quad-\quad \text { resistance at } 20^{\circ} \mathrm{C} \\
& \alpha \quad-\quad \text { temperature coefficient of resistance }(<0)
\end{aligned}
$$

AMP-B acts as a booster which deterinines the amount of power that will be applied to $R_{3}$. This circult forms a negative feedrack system. If $T_{3}$ is too low, $R_{3}$ will be 1 ess than $R_{A}$. Consequently, the gain of AMP.A will be greater than 1.0. This will cause more power to be applied to $R_{3}$, which will raise the temperature in the measurement chamber. The resistance of $R_{3}$ will Increase unt11 1t equals $R_{A}$.

\section{E. Data Analysle}

The procedures followed during a typical assay are included in the flowchart shown In FIg. 7. One of the more Important features of the calorimetric technique is that the operator may callbrate the instrunent using electrical heat standards. This ts especially vital for in-field use of the device, since severe restrictions have been placed on the transportation of plutonium calibration sources. The DAS will automatically perform the callbration for a user-selected number of input calibration powers. The microprocessor calculates the proper input reference voltage to be applied across the celibration resiatance coll. These powers simulate a set of plutonfum 


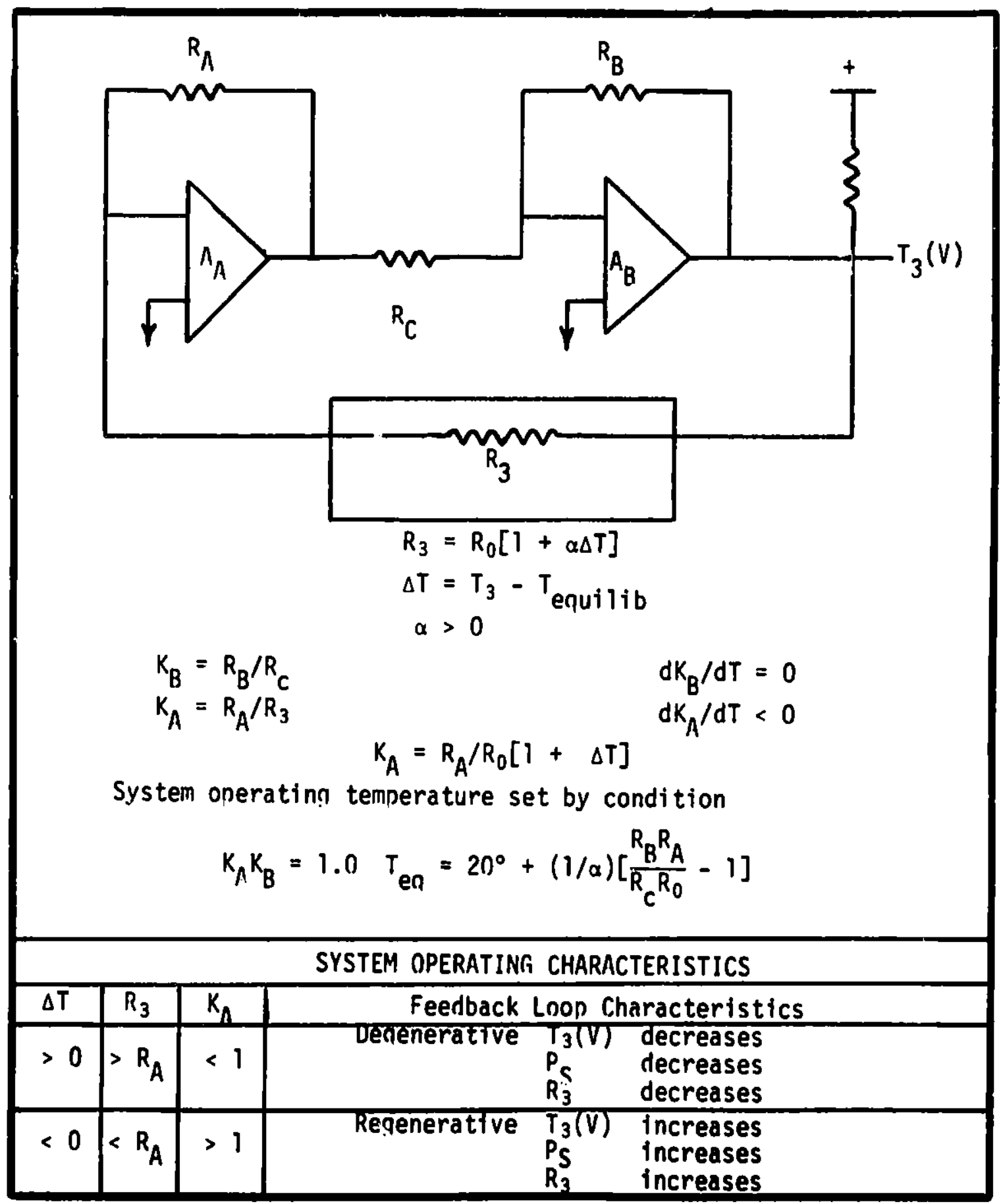

F18. 6. Res18tance thermometry and feedback control circuitry in ANL a1r-chamber calorimeters. 
Electrical Calibration

1. Apply reference voltage $\left(P_{A}\right)$

2. Monitor calorimeter output

$\left(P_{M}\right)$

3. Calculate A, B (LLSQ)

$\bar{P}_{M}=A+B \bar{P}_{A}$
Plutonium Calibration

1. Assay calibrated standard $\left(P_{K}\right)$

2. Calculate $F=P_{\text {STND }} / P_{K}$

System Stability

1. Measure $P_{C}$ for sample containing no $\mathrm{Pu}\left(\mathrm{P}_{0}\right)$

2. t-test comparison of $P_{0}$ with $A$

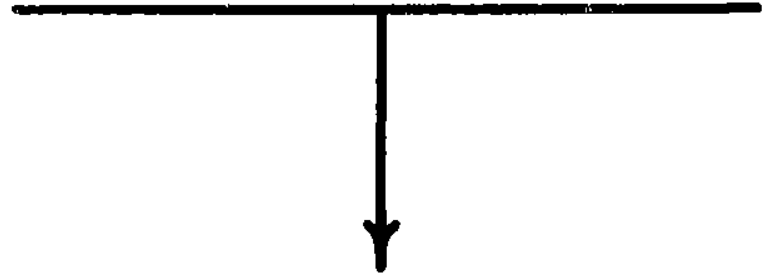

Sample Assay

1. Measure $i c$ for unknown source

2. Calculate $P_{S}=F\left(P_{C}-A\right) / B$

3. Calculate

$$
s^{2}\left(P_{S}\right)=s^{2}(\text { HDE })+s^{2}\left(\text { TEMP) }+s^{2}(\text { REP })+s^{2}(\text { CALIB })+s^{2}\left(P_{C}\right)\right.
$$

4. Calculate $M_{S}=P_{S} / P_{\text {eff }}$

5. Calculate

$$
s^{2}(M)=s^{2}\left(P_{S}\right)+s^{2}\left(P_{e f f}\right)
$$

F18. 7. Data analysis flowchart for the amall-sample calorimeter. 
standards over the measurement range of the instrument. The system then measures both the input power and the control-circuit power at each point. The results of this calibration are used in a linear least squares analysis to determine the zero-power intercept (A) and the power-measurement slope (B).

An assay is performed with a Pu standard to determine if a measurement blas exists between the electrically produced power and the radloactive-decay produced power. The results are incorporated in the normalization constant F.

If a number of samples are to be assayed, the operator will perfodically check the system stabllity by measuring the control-circuit supplied power for samples which do not contain a heat-producing source $\left(P_{0}\right)$. A t-test comparison may then be performed to assure that there has been no significant electronic drift from the calibration-determined empty-chamber power (A).

The power produced by an unknown source is then determined by the use of the above-ment loned parameters

$$
\overline{\mathrm{P}}_{S}=F\left(\overline{\mathrm{P}}_{C}-A\right) / B
$$

The uncertainty assoclated with th1s power measurement includes the followIng sources of error:

1. $s(H D E)$ - the heat-distribution error contains the uncertainty in the measurement precision due to effects of geometric position of the heat source in the sample shamber.

2. $S$ (Temp) - the ambient-temperature error contains the uncertainty due to fluctuations in the room temperature during the sssay.

3. 8 (Rep) - the sampling-reproduclbility error 18 determined by repeated measurements of the power from a single source.

4. 8 (Calif) - the callbration error Includes the uncertainties in the electrical and radioactive callbrations.

5. $a\left(\overline{\mathrm{P}}_{\mathrm{C}}\right)$ - the etet1atical uncertainty 18 defined as the etandard deviatIon of the power meagurement $+\sqrt{n}$. 
The unknown plutonium content 18 then obtained by

$$
M_{S}=\bar{P}_{\mathbf{S}} / P_{\text {eff }}
$$

and the power-measurement uncertainty 18 combined with the error in $P_{\text {eff }}$ to give the uncertainty in $\mathrm{M}_{\mathrm{S}}$.

F. Results

The results of an experiment in which a set of plutonium-containing samples were assayed by the small-sample calorimeter are given in Table IV. These samples were constructed by placing encapsulated metal sources in sand to simulate the heat-conduction properties of $\mathrm{PuO}_{2}$ powders. The sources were made from a PuAl alloy with a 98.797-Pu composition. The 1sotopic composition of the sources was determined by a 30-min gamma assay which used a version of GAMANL specifically adapted for Pu analysis. ${ }^{7} P_{\text {eff }}$ was calculated by the computational method discussed in Section B. The sample power was determined in a 4-min measurement following a 15-min equilibration period. The sample Pu mass agrees well with the reported book value over the range of sample powers tested ( $\sim 50 \%$ of full scale). A mass-determination uncertainty better than $1 \%$ was obtained in almost all cases, with the major part of this error resulting from the determination of $P_{\text {eff }}$. Various device parameters, as well as the magnitude of the error contributions, are discussed In P18. 8. 
Table IV. An analysis of 2.PR-3 plutontum samples with the ANL smal1-sample calorimeter.

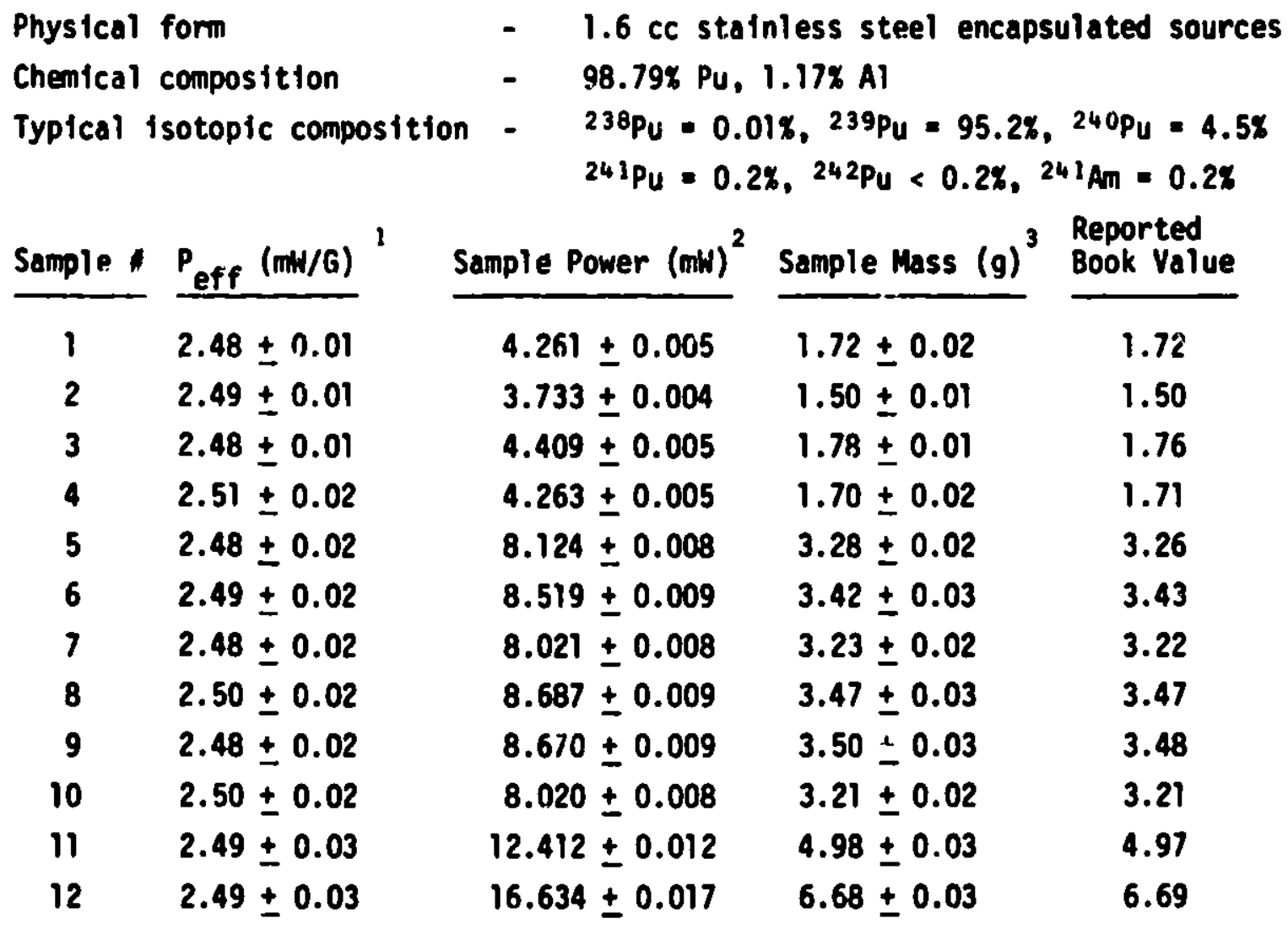

1 Determined by gammo-assay uncertainty contributions - counting statistics, 242pu blas (< $0.2 x)$

2 Determined by 20 min calorimetric analysis uncertainty contributions - counting statistics, sample heat distrib. (0.04\%) systen temperature stability $\left(0.09 \% /{ }^{\circ} \mathrm{C}\right)$ system reproductbility $(0.02 \%)$

3 Includes 0.18 uncertainty in radioactive standard calibration 
I. Physical Description

A. Data acquisition module - consisting of 8085 Microprocessor, 8K-byte nonvolatile memory, printer, and keyboard weight $-5 \mathrm{~kg}$ size $-47 \mathrm{~cm} \times 35 \mathrm{~cm} \times 16 \mathrm{~cm}$

B. Measurement module - consisting of calorimeter, sample preheater, and power supplies weight $-13 \mathrm{~kg}$ size $-30 \mathrm{~cm} \times 41 \mathrm{~cm} \times 26 \mathrm{~cm}$

II. Sample Size - up to $10 \mathrm{~g}(6 \mathrm{cc})$ of plutonium oxide

III. Environmental Parameters

A. Line power: 110 VAC $(60 \mathrm{~Hz})$ or 220 VAC $(50 \mathrm{~Hz})$ Sensitivity to line nolse - stable with $\pm 8 \mathrm{~V}$ spikes Sensitivity to voltage fluctuations - stable at $110 \mathrm{~V} \pm 20 \%$

B. Room temperature operating range $-10.5^{\circ} \mathrm{C}-35.0^{\circ} \mathrm{C}$ Temperature drift $<0.09 \% / \mathrm{C}^{\circ}$

IV. System Equilibration Time (Pre-heated Sample)

A. Metal encapsulation - $15 \mathrm{~m} / \mathrm{n}$

B. Double polyethelyne bag encapsulation - $30 \mathrm{~m} f \mathrm{n}$

V. System Power Measurement Precision

A. Sample heat distribution uncertainty - $0.04 \%$

B. Sampling reproducibility uncertainty - $0.02 \%$

C. System temperature stabllity - $0.09 \% / C^{\circ}$

D. Typical statistical uncertainty (4 min assay) $\quad-\quad 0.018$

Combined precision: $s\left(P_{0}\right) / P_{0}=0.1 \%$

F18. 8. Data sheet for the ANL amall-sample calor Imeter. 


\section{REFERENCES}

1. S. R. Gunn, Radiometric Calorimetry: A Review, Nuclear Instruments and Methods 29(1) (1967).

2. N. S. Beyer, R. N. Lew18, and R. B. Perry, A Portable Dry Calorimeter for Nondestructive Assay of Mixed-Oxide Fuel Rods, Nuclear Materials Management, 1(3), 170-196 (1972).

4. ANSI N1j.22-1975, American National Standard Culibration Techniques for the Calorimetric Assay of Pu-Bearing Solids Applied to Nuclear Materials Control.

5. W. W. Rodenbur8, Fundanentals of Calorimetric Assay, Proceedings of the Symposium on the Calorimetric Assay of Plutonium, p. 14 (1973).

6. J. M. Meadows, The Alpha and Spontaneous Fisoion Half-lives of ${ }^{242} \mathrm{Pu}$, ANL/NDM-38 (1977).

7. D. M. B1shop and I. N. Taylor, Calorimetry of Plutonito Recycle Fuels: Applications, Incentives, and Needs, Proceedings of the Symposium on the Calorimetric Assay of Plutonium, p. 75 (1973).

8. R. Gunnink, A System for Plutonium Analysis by Camma-Spectrometry, UCRL-51577 (1974).

9. N. S. Beyer, R. N. Lew1s, and R. B. Perry, Small, Fast-Response Calorimeters Developed at ANL for the Nondestmetive Assay of Plutonizm Fuel Rods, Proceedings of the Symposium on the Calorimetric Assay of Plutonium, P. 99 (1973).

10. N. S. Beyer, R. B. Perry, R. W. Brandenburg, and R. N. Lew1s, Four Paseive Assay Techniques Applied to Mixed-Oxide Fuel, All-7906 (1972). 
Distribution for ANL-78-33 and ISPO-16

\section{Internal:}
C. T. Roche (15)
R. J. Epstein
R. B. Perry (15)
M. A. Kanter
R. N. Lewis
P. A. Michaels
E. A. Jung
A. B. Krisciunas
J. R. Haumann
ANL Contract Copy
M. J. Ryan
ANL Libraries (5)
S. J. Rudnick
TIS Files (4)

\section{External:}

DOE-TIC, for distribution per UC-15 (328)

Manager, Chicago Operations office

Chlef, Chicago Patent Group

President, Argonne Universities Assoctation

L. Green, International Safeguards Project Office, c/o Brookhaven National Laboratory (50)

N. S. Beyer, c/o International Atomic Energy Agency, Vienna 